\title{
PENERAPAN 3M TERHADAP PENCEGAHAN KEJADIAN DBD DI WILAYAH PUSKESMAS PANAMBUNGAN KOTA MAKASSAR
}

\section{THE IMPLEMENTATION OF 3M IN THE PREVENTION OF DHF CASES IN THE WORKING AREA OF PANAMBUNGAN HEALTH CENTER, MAKASSAR CITY}

Fransiska Lang
Fakultas Kesehatan
Masyarakat
Universitas Pancasakti
Makassar, Indonesia ${ }^{1}$
email:
anchykballang@gmail.
com

Muharti Syamsul $^{2}$ Fakultas Kesehatan Masyarakat Universitas Pancasakti Makassar, Indonesia ${ }^{2}$ email:

muhartisyamsul@unpa cti.ac.id

\section{Nur Hamdani Nur ${ }^{3}$ \\ Fakultas Kesehatan \\ Masyarakat \\ Universitas Pancasakti \\ Makassar, Indonesia ${ }^{3}$ \\ email: \\ hamdani.nur@unpacti. ac.id}

\section{IJI Publication}

E-ISSN: xxxx-xxxx Vol. 1, No. 1, pp. 38-43 Juni 2021

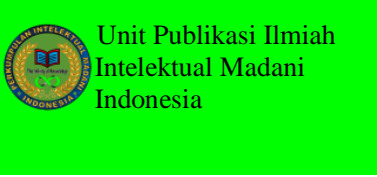

Abstrak: Penyakit Demam Berdarah Dengue (DBD) atau Dengue Haemorrhagic Fever (DHF) merupakan salah satu penyakit menular yang disebabkan oleh virus dengue melalui gigitan nyamuk Aedes. Salah satu penyebab dari kejadian DBD ini adalah buruknya sanitasi lingkungan disekitar pemukiman warga, upaya pencegahan penyakit DBD adalah memutuskan rantai penularan dengan dengan cara mengendalikan vector melalui Pemberantasan Sarang Nyamuk (PSN) dan pelaksanaan gerakan 3M. Penelitian ini bertujuan untuk mengetahui gambaran penerapan 3M di wilayah kerja Puskesmas Panambungan Kota Makassar. Jenis penelitian ini merupakan penelitian Kuantitatif dengan pendekatan Deskriptif. Pengumpulan data dilakukan selama September-Oktober 2020. Populasinya adalah masyarakat yang tinggal di Kelurahan Panambungan. Data dikumpulkan dengan cara wawancara menggunakan koesioner dan lembar observasi. Hasil penelitian menunjukan bahwa kegiatan menguras tempat penampungan air di masyarakat Panambungan yaitu sebanyak $67(83.8 \%)$ yang melaksanakan menguras tempattempat penampungan air dengan baik dan $13(16.2 \%)$ yang kurang melaksanakan penerapan menguras tempat penampungan air. Kegiatan mengubur barang bekas yaitu sebanyak 18 (22.5\%) yang melaksanakan mengubur barang bekas dengan baik dan $62(77.5 \%)$ yang kurang melaksanakan penerapan mengubur barang bekas. Dan kegiatan menutup tong air yaitu sebanyak $24(30.4 \%)$ yang melaksanakan menutup tempat penampungan air dengan baik dan 55 (69.6\%) yang kurang melaksanakan penerapan menutup tempat penampungan air. Berdasarkan hasil penelitain, disarankan kepada masyarakat agar memperhatiakn kondisi lingkungan untuk mencegah terjadinya penyakit DBD.

Kata Kunci : DBD, Menguras, Mengubur, Menutup.

Abstract: Dengue Hemorrhagic Fever (DHF) is a contagious disease caused by the dengue virus through the bite of an Aedes mosquito. One of the causes of this DHF incident is the poor sanitation of the environment around residential areas, efforts to prevent dengue fever are breaking the transmission chain by controlling the vector through the eradication of mosquito nests (PSN) and the implementation of the $3 M$ movement.This study aimed to determine the description of the implementation of $3 M$ in the working area of Panambungan Health Center, Makassar.The type of this research was is a quantitative study with a descriptive approach. Data collection was carried out from September to October 2020. The population was all people who live in Kel. Panambungan. Data were collected through interviews using an observation sheet and a questionnaire. In the activity of draining water reservoirs, 67 (83.8\%) families conducted this activity properly, while the other 13 (16.2\%) families less conducted this activity. In the activity of burying used goods, $18(22.5 \%)$ families conducted this activity properly, while the other $62(77.5 \%)$ families less conducted this activity. Finally, in the activity of closing water reservoirs, 24 (30.4\%) families conducted this activity properly, while the other 55 (69.6\%) families less conducted this activity. Based on the results of the study, it is recommended to the public to pay attention to environmental conditions to prevent the occurrence of DHF.

Keywords: DHF, Draining, Burying, Closing 


\section{PENDAHULUAN}

Penyakit Demam Berdarah Dengue (DBD) atau Dengue Haemorrhagic Fever (DHF) merupakan salah satu penyakit menular yang disebabkan oleh virus dengue melalui gigitan nyamuk aedes aegypti. (Kementerian Kesehatan RI, 2015). Penyakit yang disebabkan oleh infeksi virus dengue yang masih menjadi masalah kesehatan masyarakat. Virus dengue merupakan sejenis virus dari keluarga flaviviridae dan genus flavivirus yang disebarkan oleh nyamuk aedes aegypti selama ini dikenal hanya sebagai pembawa virus dengue, namun kenyataannya nyamuk jenis ini juga bisa membawa virus, jadi jika dan DBD ditularkan melalui perantara yang sama yaitu aedes aegypti yang masih menyerang.

Penanganan masalah penyakit DBD dan jika saat ini adalah dengan memberantas sarang nyamuk penularnya (PSN DBD), belum optimalnya pengetahuan dan sikap masyarakat terkait dengan lingkungan sekitar dapat mempengaruhi pencegahan DBD dan jika dalam menjalankan program $3 \mathrm{M}$ inimasih sangat kurang.

Organization WHO memperkirakan Insiden DBD telah tumbuh meningkat secara dramatis di seluruh dunia dalambeberapa dekade terakhir. Angka-angkayang sebenarnya dari kasus DBD yang tidak dilaporkan dan banyak kasus yang kesalahan klasifikasi. Salah satu perkiraan baru-baru ini menunjukkan bahwa infeksi. DBD sebesar 390 juta per tahun. Penelitian lain, memperkirakan 3,9 milyar orang, di 128 negara, berada pada daerah yang beresiko terinveksi virus dengue terutama yang tinggal di daerah perkotaan di Negara tropis dan subtropis (WHO, 2018).

Demam Berdarah dengue masih menjadi persoalan di Indonesia karena angka morbiditas DBD sekarang belum mencapai target pemerintah yaitu kurang dari 49 per 100.000 penduduk. Data yang diperoleh dari Kementrian Kesehatan (Kemenkes) menyebutkan tahun 2019 angka morbiditas DBD 59,02 per 100.000 penduduk. Jumlah ini menanjak naik dan mencapai puncak pada tahun 2015 yaitu 65,7per 100.000 penduduk. Tahun berikutnya angka ini menurun pesat menjadi 27,67 per 100.000 penduduk. Angka morbiditas DBD kembali naik pada tahun berikutnya menjadi 37,23 per 100.000 penduduk. Pada tahun 2017 tercatat angka kesakitan DBD mencapai 50,75 per 100.000 penduduk.(Kemenkes 2019).

Dinas Kesehatan (Dinkes) Kota Makassar mencatat 22 kasus DBD terjadi selama 2019,itu tersebar di hampir seluruh kecamatan Kota Makassar, meski begitu sejauh ini hanya 1 orang yang meninggal akibat DBD. Pasalnya hampir semua pasien di tangani dengan baik, (Dinkes Kota Makassar 2018).

Dinas Kesehatan (Dinkes) Kota Makassar mencatat bahwa hingga memasuki pertengahan Maret 2020, jumlah kasus demam berdarah (DBD) mencapai 65 kasus. Data tersebut merupakan kasus yang terjadi sejak januari lalu. Januari ada 23 kasus, di tambah 42 kasus di bulan februari hingga maret, tapi tidak ada kematian, (Dinkes Kota Makassar 2020). Di kecamatan Mariso terlebih khusus di wilayah 
kerja Puskesmas Panambungan terdapat banyak kasus demam berdarah (DBD) yang di temukan.

Berdasarkan data awal yang saya ambil di Puskesmas Panambungan, dimana pada tahun 2017 terdapat 5 kasus demam berdarah (DBD) dan tidak ada yang meninggal dunia. Pada tahun 2018 terdapat 5 kasus demam berdarah (DBD) dan tidak ada yang meninggal dunia. Pada tahun 2019 terdapat 10 kasus demam berdarah (DBD) dan tidak ada yang meninggal dunia. Dan pada bulan Januari-Maret 2020 terdapat 8 kasus demam berdarah (DBD), dan belum ada yang meninggal dunia. Dengan semakin bertambahnya kasus demam berdarah (DBD) di Puskesmas Pannambungan ini merupakan petunjuk bahwa masalah kesehatan masyarakat masih merupakan beban, (Dinkes Kota Makassar 2019).

Upaya pencegahan terhadap penularan DBD dilakukan dengan pemutusan rantai penularan DBD berupa pencegahan terhadap gigitan nyamuk aedes aegypti. Kegiatan yang optimal adalah melakukan Pemberantasan Sarang Nyamuk (PSN) dengan cara "3M" selain itu juga dapat dilakukan dengan larvasidasi (Basri \& Hamzah, 2017) dan pengasapan (fogging) (Ariyati, 2015). Penelitian ini dilakukan untuk mengetahui Penerapan 3M terhadap pencegahan kejadian demam berdarah (DBD) di wilayah kerja puskesmas panambungan kota Makassar Tahun 2020.

\section{METODE}

Penelitian ini merupakan penelitian kuantitatif menggunakan desain deskriptif dengan tujuan untuk menggambarkan suatu keadaan secara objektif dan digunakan untuk memecahkan atau menjawab permasalahan yang sedang terjadi pada situasi sekarang (Notoatmodjo. S, 2010). Penelitian ini dilaksanakan di wilayah Kerja Puskesmas Pannambungan kota Makassar. Populasi dalam penelitian ini adalah rumah yang berada di Kelurahan Pannambungan wilayah kerja Puskesmas Pannambungan sebanyak 12.324 jiwa dan 80 sampel. Teknik pengambilan sampel menggunakan Probality Sampling (random Sampling). Instrumen yang digunakan dalam penelitian ini adalah kuesioner dan lembar observasi. Dalam menganalisis data peneliti menggunakan bantuan program SPSS.

\section{HASIL DAN DISKUSI}

Hasil Penelitian

Tabel 1

Karakteristik responden

\begin{tabular}{lcc}
\hline \multicolumn{1}{c}{ Karakteristik } & $\mathrm{n}$ & $\%$ \\
\hline Umur & & \\
$20-30$ & 13 & 16,2 \\
$31-40$ & 32 & 40 \\
$41-50$ & 22 & 27,5 \\
$>51$ & 13 & 16,2 \\
Jenis kelamin & & \\
Laki-laki & 34 & 42.5 \\
perempuan & 46 & 57.5 \\
Tingkat pendidikan & & \\
SD & 38 & 47.5 \\
SMP & 13 & 16.2 \\
SMA & 26 & 32.5 \\
Sarjana & 3 & 3.8 \\
Jumlah & & 100
\end{tabular}

Sumber: Data Primer, 2020

Pada tabel 1 menunjukan bahwa jumlah responden paling dominan pada umur $31-40$ tahun yaitu sebanyak 32 responden $(40 \%)$ sedangkan yang paling sedikit adalah umur 2030 tahun dan umur 51 tahun keatas yaitu sebanyak 13 responden (16.2\%), kemudian 
berdasarkan jenis kelamin, menunjukkan bahwa

jumlah responden yang berjenis kelamin perempuan lebih banyak jika dibandingkan dengan jenis kelamin laki-laki yaitu sebanyak 46 responden $(57.5 \%)$ sedangkan berdasarkan tingkat pendidikan menunjukkan bahwa jumlah responden paling dominan pada tingkat pendidikan SMA yaitu sebanyak 26 responden $(32.5 \%)$ sedangkan yang paling sedikit adalah tingkat pendidikan S1 yaitu sebanyak 3 responden $(3.8 \%)$.

Tabel 2

Hasil Uji Univariat Menguras Tempat Penampungan Air

\begin{tabular}{ccc}
\multicolumn{1}{r}{ Menguras } & $\mathrm{n}$ & $\%$ \\
\hline Baik & 67 & 83.8 \\
kurang baik & 13 & 16.2 \\
Total & 80 & 100
\end{tabular}

Sumber: Data Primer, 2020

Berdasarkan tabel 2 diatas menunjukan bahwa dari 80 responden yang diteliti, terdapat $67(83.8 \%)$ yang melaksanakan menguras tempat tempat penampungan air dengan baik dan $13(16.2 \%)$ responden yang kurang melaksanaka penerapan menguras tempat penampungan air.

Tabel 3

Hasil Uji Univariat Mengubur Barang Bekas

\begin{tabular}{lcc}
\hline \multicolumn{1}{c}{ Mengubur } & $\mathrm{n}$ & $\%$ \\
\hline Baik & 18 & 22.5 \\
Kurang baik & 62 & 77.5 \\
Total & 80 & 100 \\
\hline Sumber: Data Primer, 2020 & &
\end{tabular}

Berdasarkan tabel 3 diatas menunjukan bahwa dari 80 responden yang diteliti, terdapat $18(22.5 \%)$ yang melaksanakan mengubur barang bekas dengan baik dan $62(77.5 \%)$ responden yang kurang melaksanakan penerapan mengubur barang bekas.
Tabel 4

Hasil Uji Univariat Menutup Tempat Penampungan Air

\begin{tabular}{lcc}
\hline Menutup & $\mathrm{n}$ & $\%$ \\
\hline baik & 24 & 30.4 \\
kurang baik & 55 & 69.6 \\
Total & 80 & 100 \\
\hline
\end{tabular}

Sumber: Data Primer, 2020

Berdasarkan tabel 4 diatas menunjukan bahwa dari 80 responden yang diteliti, terdapat $24(30.4 \%)$ yang melaksanakan menutup tempat penampungan air dengan baik dan 55 (69.6\%) responden yang kurang melaksanakan penerapan menutup tempat penampungan air.

\section{Pembahasan}

\section{Menguras Tempat Penampungan Air}

Dari hasil penyebaran kuisioner terhadap 80 responden diperoleh hasil penelitian terdapat 67 (83.8\%) yang melaksanakan menguras tempat penampungan air dengan baik dan 13 (16.2\%) responden yang kurang melaksanakan penerapan menguras tempat penampungan air dengan baik. Dari data yang diperoleh rata-rata masyarakat panambungan melaksakan kegiatan menguras tempat penampungan air dengan baik. Ini bertentangan dengan pengamatan peneliti bahwa, kegiatan menguras tempat penampungan air di wilayah Panambungan masih sangat kurang,dimana rata-rata yang diamati peneliti tong penampungan air yang kotor, bak mandi juga penuh dengan kotoran yang berwarna kuning mudah, dan tempat penampungan air minim yang kotor.

\section{Mengubur Barang Bekas}

Dari hasil penyebaran koesioner terhadap 80 responden diperoleh hasil penelitian terdapat 
$18(22.5 \%)$ yang melaksanakan mengubur barang bekas dengan baik dan 62 (77.5\%) responden yang kurang melaksanakan penerapan mengubur barang bekas. Dapat di simpulkan bahwa kegitan mengubur barang bekas atau mendaur ulang barang bekas di panambungan masih sangat kurang. Ini sejalan dengan apa yang di amati peneliti bahwa ratarata masyarakat Panambungan tidak melakukan kegiatan mengubur sampah atau sejenisnya yang dapat menampung air, dimana sampah pelastik, dan kaleng-kaleng di buang dan ada yang berserakan dikompeleks tempat tinggal masyarakatnya.

\section{Menutup Tempat Penampungan Air}

Dari hasil penyebaran koesioner menunjukan bahwa dari 80 responden yang diteliti, terdapat $24(30.4 \%)$ responden yang melaksanakan menutup dengan baik dan 55 (69.6\%) responden yang kurang melaksanakan penerapan menutup. Dapat di simpulkan bahwa rata-rata masyarat Panambungan kurang melakukan penunutupan terhadap tempat penyimpanan airnya. Ini hampir sepaham dengam apa yang di amati peneliti bahwa, ratarata tempat atau wadah penyimpanan air masyarat jarang ada penutupnya.

\section{KESIMPULAN}

Hasil penelitian menunjukan bahwa kegiatan menguras tempat penampungan air di masyarakat Panambungan yaitu sebanyak 67 $(83.8 \%)$ yang melaksanakan menguras tempattempat penampungan air dengan baik dan 13 (16.2\%) yang kurang melaksanakan penerapan menguras tempat penampungan air. Kegiatan mengubur barang bekas yaitu sebanyak 18 (22.5\%) yang melaksanakan mengubur barang bekas dengan baik dan 62 (77.5\%) yang kurang melaksanakan penerapan mengubur barang bekas. Dan kegiatan menutup tong air yaitu sebanyak 24 (30.4\%) yang melaksanakan menutup tempat penampungan air dengan baik dan 55 (69.6\%) yang kurang melaksanakan penerapan menutup tempat penampungan air. Berdasarkan hasil penelitain, disarankan kepada masyarakat agar memperhatiakn kondisi lingkungan untuk mencegah terjadinya penyakit DBD.

\section{REFERENSI}

Ariyati, Ika Setia. (2015). Hubungan Pemberantasan Sarang Nyamuk (PSN 3M Plus) Dengan Kemampuan Mengamati Jentik Dengan Kejadi-An DBD Di Kelurahan Tembalang, Kota Semarang. Skripsi, niversitas Negeri Semarang

Achmandi. (2015) Peran Masyarakat Dalam Pemberantasan DBD. tanggal 16 Mei 2015 dari http://WWW.Gizi. Net

Andriyani. (2016) Petunjuk Teknis Survei Jentik Aedes Aegypti dari Survei Pengetahuan dan Sikap Masyarakat terhadap Demam Berdarah Dengue. Jakarta: Ditjen PPM dan PLP.

Dapartemen Kesehatan Republik Indonesia. (2017). Indicator Sehat 2018 Pedoman Penetapan Indicator Propinsi Sehat dan Kabupaten/Kota Sehat. Keputusan Menteri Kesehatan RI No.1202 / Menkes / SK / VIII / 2017, Jakarta.

Dapartemen Kesehatan (2015). Modul Pelatihan Pengelola Program Pengendalian Penyakit Demam Berdarah Dengue di Indonesia Jakarta. 
Diyono. (2014). Penggunaan Abate dan Bacillus

Thuringensis var. Israelensis di Kantor

Kesehatan Pelabuhan Kelas II Sa-marinda

Wilayah Kerja Sanggata Terhadap

Kematian Larva Aedes sp. Al-Sihah: The

Pub-lic Health Science Journal, 9(1).

Dinas Kesehatan Sulawesi Selatan. (2018). Data

Penyakit Demam Berdarah DB4MK

Sulawesi Selatan 2018. Dinkes Sulsel.

Denendro. (2014). Hubungan Pemberantasan Sarang Nyamuk (PSN) DBD Dengan Keberadaan Jentik Nyamuk Aedea Aegypti Di Wilayah Endemis DBD Kelurahan Kassi - Kassi Kota Makassar. Kesehatan Lingkungan. Universitas Hasanuddin Makassar.

Djunaedi. (2013). Perbedaan Praktik PSN 3M Plus Di Kelurahan Percontohan Dan Non Percontohan Program Pemantauan Jentik Rutin Kota Semarang. Jurnal Entomologi Indonesia.

Firdausi Ramadhani. (2019). Pelaksanaan PSN $3 M$ Plus untuk Pencegahan Demam Berdarah Dengue (Studi Kasus Masyarakat Desa Kamal).

Hamzah, E., \& Basri, S. (2016). Perbedaan Ovitrap Indeks Botol, Ember dan Port Mosquito Trap sebagai Perangkap Nyamuk Aedes sp. di Ar-ea Kantor Kesehatan Pelabuhan Kelas II Sa-marinda Wilayah Kerja Sangatta Kabupaten Kutai Timur. HIGIENE: Jurnal Kesehatan Lingkungan, 2(3), 155-158.

Hasan., Amrul., Ayubi, Dian. (2015). Hubungan Pemberantasan Sarang Nyamuk dan Kejadian DBD di Kota Bandar Lampung. Diakses tanggal 16 Mei 2015 dari http://WWW.JournalKesmas.org

Herms. (2006). Apa Yang Anda katakan Tentang Demam Berdarah.Yogyakarta: B First.

Kementrian Kesehatan RI. (2019). Profil Kesehatan Indonesia 2019. Jakarta: Kementrian Kesehatan RI.
Lucky radita Alma. (2014). Perilaku 3M, Abatisasi dan Keberadaan Jentik Aedes Hubungannya dengan Kejadian Demam Berdarah Dengue. , 3(2), 111-118.

Muhammad Saleh. (2018). Hubungan Pemberantasan Sarang Nyamuk (PSN) dengan Keberadaan Jentik Nyamuk Aedes aegypti di Wilayah Kerja Puskesmas Pancana Kab. Barru.

Nadesul, Handrawan. (2017). Carah Mudah Mengalahkan Demam Berdarah. Jakarta: Penerbit Buku Kompas

Nuryanti E. (2015). Perilaku Pemberantasan Sarang Nyamuk Di Masyarakat. Jurnal Kesehatan Masyarakat, 9(1): 15 - 23.

Purnama SG, Satoto TB, Prabandari Y. (2018). Pengetahuan, Sikap dan Perilaku PSN Terhadap Infeksi Dengue Di Kecamatan Denpasar Selatan, Kota Denpasar, Bali. Arc. Com. Health, 2(1): 20 - 27.

Priesley, Reza Rusjdi. (2018). Hubungan Antara Pengetahuan dan Persepsi Dengan Perilaku Masyarakat Dalam Pemberantasan Sarang Nyamuk Demam Berdarah Dengue Di Kota Kediri. Tesis. Fakultas Kedokteran Keluarga Universitas Sebelas Maret, Surakarta.

Richard dan Davis. (1977). Pembrantasan Vektor DBD Di Indonesia diakses $16 \mathrm{Mei}$ 2018. http://www.Ussudigitallibrari.ac. Id.

Satari dan Meilasari. (2004). Demam Berdarah Dengue. 2004. http://www.dkkpbpp.com/indekx?option= com/content $/ \mathrm{id}=164 / \mathrm{It}$ emid=47.

Sunaryo. (2014). Hubungan Pengetahuan Keluarga Tentang Penyakit DHF dengan Sikap Keluarga dalam Pencegahan Penyakit DHF. Jurnal Florence, 4(2)..

Soegijanto. (2014). Kepadatan Jentik Aedes aegypti Sebagai Indikator Keberhasilan Pemberantasan Sarang Nyamuk (3M PLUS) Di Kelurahan Grondol Wetan Semarang. Jurnal Makara, 12 (1), 13-19. 
Utami. (2014). Efektifitas Pelaksanaan 3M

(Menguras, Menutup, dan Mengubur)

Untuk Menurunkan Kejadian Demam

Berdarah Dengue (DBD) di Kota Blitar

Periode 2012-2013. Thesis. Malang:

Universitas Muhammadiyah

WHO. (2015). Dengue and Severe Dengue Geneve. World Helath Organization

Widoyono. (2011). Penyakit Tropis Epidemiologi, Penularan, Pencegahan dan Pember-antasannya. Jakarta: Erlangga

Warisidi. (2018). Faktor-faktor yang berhubungan dengan perilaku masyarakat dalam pemberantasan sarang nyamuk demam berdarah dengue (PSN-DBD) di kota Jambi Tahun 2003. Perpustakaan Universitas Indonesia.

Yatim. (2013). Dengue. Yogyakarta, Medika, FK UGM.

Yuyun Priwahyuni. (2014). Mengenai Perilaku Masyarakat tentang Menguras, Menutup, Mengubur (3M) Plus terhadap Bebas Jentik. 